\title{
Cattle Diets on Semidesert Grassland: Botanical Composition
}

\section{R. E. ROSIERE, R. F. BECK, AND J. D. WALLACE}

Highlight: Botanical composition of cattle diets on semidesert rangeland was studied by microhistological techniques. Cattle consumed $56 \%$ of all species available. Dietary portions of grasses, forbs, shrubs, and unidentifiable plants averaged 45, 32, 19, and 6\%, respectively. Composition of diets changed with seasons. Grass contents of diets were highest in summer and lowest in spring. Mesa dropseed was the most common species in diets. Perennial grasses represented dependable sources of forage, but never comprised more than 50\% of the steers' diets in any season, and should not be used as the sole criterion for estimating forage production or determining stocking rates. Shrub portions were highest in spring when soaptree yucca was grazed almost exclusively. Forb fractions of diets varied little among seasons but were highest in winter. Forbs and shrubs comprised over one-half of the diets in certain seasons and should be grazed in these seasons if full benefit is to be derived from them. Preference ranking of forage plants evaluated selectivity and palatability but preference trends were inconsistent and most affected by species availability.

Authors are former graduate research assistant, range ecologist, and range nutritionist, respectively, Department of Animal, Range and Wild life Sciences, New Mexico State University, Las Cruces.

This report is Journal Article 517 from the Agricultural Experiment Station, New Mexico State University.

Manuscript received May 31, 1974.
Semidesert grassland occupies 36 million ha in the Southwest (Campbell and Craft, 1939) with most ranges being grazed by livestock. These ranges are usually grazed yearlong, but Valentine (1967) proposed a seasonal suitability grazing system to restore deteriorated pastures. Cattle diets from this system are compared to those under continuous grazing.

Effective range management depends upon identification of plants which are palatable and nutritious to livestock. Most plants on desert grassland contribute more to cattle diets than is usually believed (Galt et al., 1969). The investigation reported here was initiated to examine species composition of cattle diets further and to compare forage under continuous vs seasonal suitability systems.

\section{Experimental Procedure}

Study pastures were on the New Mexico State University Ranch, $38 \mathrm{~km}$ north of Las Cruces, where the climate is arid and the frost-free period averages 200 days. Average annual precipitation for a 57 -year period was $23 \mathrm{~cm}, 51 \%$ of which fell during the major growing season in July, August, and September (Table 1). Rainfall from July through September was $32 \%$ 
above average in 1972 but $45 \%$ below average in 1973 .

Data were collected from one continuously grazed pasture (No. 15 which contained $1348 \mathrm{ha}$ ) and three pastures within a seasonal suitability system (Nos. $3 \mathrm{~N}, 3 \mathrm{~S}$, and $3 \mathrm{~W}$, which contained 451, 526, and 668 ha, respectively). Vegetation was semidesert grassland varying from homogenous stands of black grama (see Table 2 for scientific names) to sand dune areas dominated by mesquite. Botanical compositions of pastures (Table 2) were derived while measuring plant density in circular plots of variable size (Rosiere, 1973). Herbage available $(\mathrm{kg} / \mathrm{ha})$ on each pasture duirng each season was calculated by multiplying the average weight of a species times the density of that species in a hectare. Density estimates for pastures by seasons were obtained from 100 randomly located plots.

Forage samples were collected from four esophageal fistulated Hereford steers during 10-day periods in August and October of 1972 and in January, May, and July-August of 1973. Steers grazed study pastures for 2 to 3 weeks prior to sampling periods, except in October, 1972. Pastures were sampled once a day at sunrise after steers had been penned overnight. The year-long use pasture and one pasture in the seasonal suitability system were sampled on alternate days each 10-day period. Steers were driven to different plant communities (i.e., black grama dropseed grassland, mesquite sand dunes, annual grass-forb sites, etc.) within each pasture and then

Table 1. Average long term monthly precipitation and monthly precipitation for 1972 and 1973 on study pastures.

\begin{tabular}{|c|c|c|c|}
\hline \multirow{3}{*}{ Months } & \multicolumn{3}{|c|}{ Precipitation $(\mathrm{cm})$} \\
\hline & \multirow{2}{*}{$\begin{array}{l}\text { Jornada Exp. Range } \\
\text { long term average }{ }^{1}\end{array}$} & \multicolumn{2}{|c|}{ College Ranch } \\
\hline & & 1972 & 1973 \\
\hline January & 1.4 & 0.6 & 1.8 \\
\hline February & 1.1 & 0.0 & 3.8 \\
\hline March & 0.7 & 0.0 & 0.7 \\
\hline April & 0.6 & 0.0 & 0.0 \\
\hline May & 0.7 & 1.7 & 4.1 \\
\hline June & 1.4 & 4.1 & 1.2 \\
\hline July & 4.1 & 4.3 & 3.6 \\
\hline August & 4.3 & 9.5 & 3.4 \\
\hline September & 3.7 & 2.4 & 0.2 \\
\hline October & 2.3 & 5.6 & 0.0 \\
\hline November & 0.9 & 0.0 & 0.0 \\
\hline December & 1.4 & 3.8 & 0.2 \\
\hline Average & 22.6 & 32.0 & 19.0 \\
\hline
\end{tabular}

${ }^{1}$ Average since 1915 at US Weather Reporting Station on Jornada Experimental Range, $15 \mathrm{~km} \mathrm{NE}$ of study pastures (US Com merce Dep., 1972).

${ }^{2}$ Data are average of 7 rain gauges on or near study pastures.

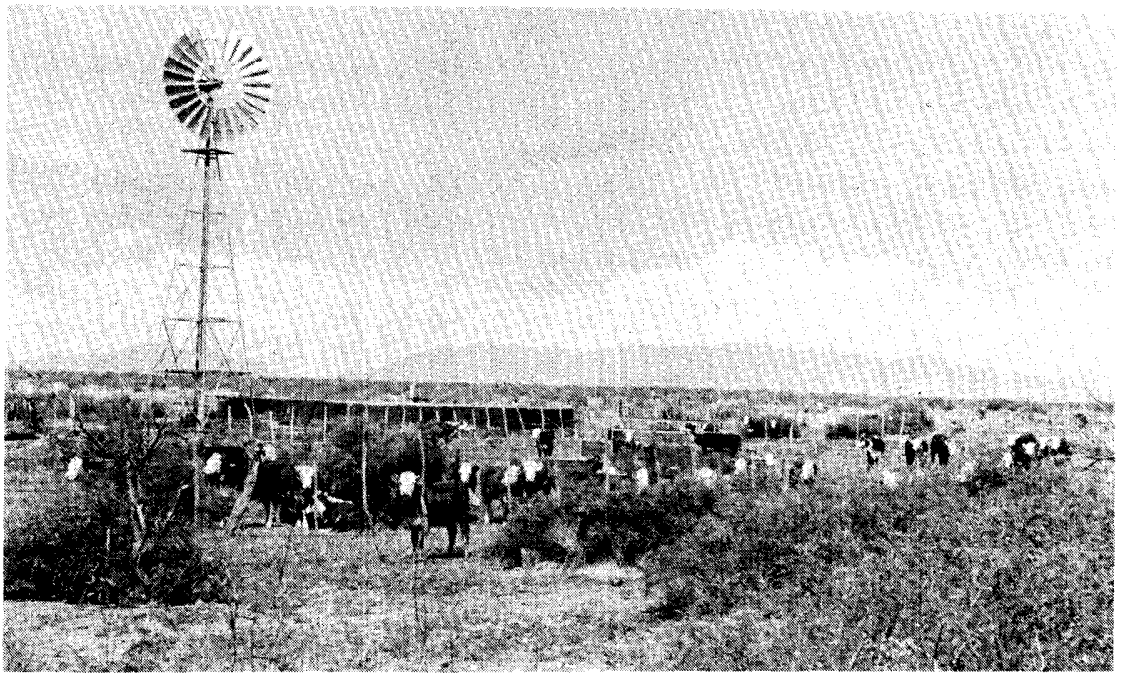

permitted to graze at will until approximately $1 \mathrm{~kg}$ of plant material was obtained. Collected forage was dried at $55^{\circ} \mathrm{C}$ for $24 \mathrm{hr}$ in a forced-air oven and then ground through a $1 \mathrm{~mm}$ screen in a Wiley mill.

Species composition of cattle diets was determined by a microscopic technique modified from Sparks and Malechek (1968). Microscope reference slides of plant species growing in study pastures and slides of fistulae-collected forage were prepared by covering ground herbaceous material with synthetic resin mounting media and cover slips. Plant particles in slides from diet samples were identified by comparing with species reference slides. Identification was by histological characteristics as reported by Free et al. (1971).

Statistical evaluation was by split plot analysis of variance with Tukey's procedure used to test differences among means (Steel and Torrie, 1960). Preference "ranks" developed from preference indicies (Van Dyne and Heady, 1965) were used to evaluate species preference by cattle.

\section{Results and Discussion}

Of the 52 plant species found on the year-long pasture and the 50 species on the seasonal suitability pastures, 28 species were identified in the diets, plus a small number of unidentified species. Twenty species were found to comprise $84 \%-95 \%$ of the steers' diets in all seasons (Table 3). Some species which were observed being grazed were not found in slides of forage. Some plant particles could not be identified due to absence of unique histological features and were often a process of elimination.

Proportions of grasses, forbs, and shrubs in diets changed among seasons
(Table 4). Significant changes were also found in the forage available in standing crop among seasons (Table 3). Similar trends were observed on pinyon-juniper grassland (Thetford et al., 1971) and shortgrass plains (Beck, 1969). Grass content did not differ significantly in the two summer diets or between fall and summer diets. Shrub content was highest in spring when large quantities of soaptree yucca were consumed. Inconsistent seasonal variability existed in forb portions of diets.

Preference ranks (Table 3) helped explain differences in selectivity. A rank of "c" (P.I. $=0.7-1.3)$ indicated that the percentage of a species in the diets was the same as in available herbage (i.e., no selectivity). Preferencc higher or lower than " $c$ " demonstrated selection for or against species, respectively. Preference alone did not always account for proportions of species in diets, because availability was also a major factor influencing dietary composition.

Preference trends were usually inconsistent. For a given species, preference ranks might differ considerably between pastures within season, but in another season ranks for that species might be similar. This, also, indicated that availability affected preference. Studies have shown that preference changed as grazing intensity increased. Leigh and Mulham (1966) found that $56 \%$ of sheep diets were comprised of a species that formed only $1 \%$ of herbage but that portions in diets decreased as availability decreased. Thus, high preferences lasted only short periods. In this study similar results were noted when the amount 
Table 2. Plant composition (\%) and total herbage production $(\mathrm{kg} / \mathrm{ha})$ on year long (15) and seasonal suitability (3N, $3 \mathrm{~S}$, $3 \mathrm{~W})$ pastures.

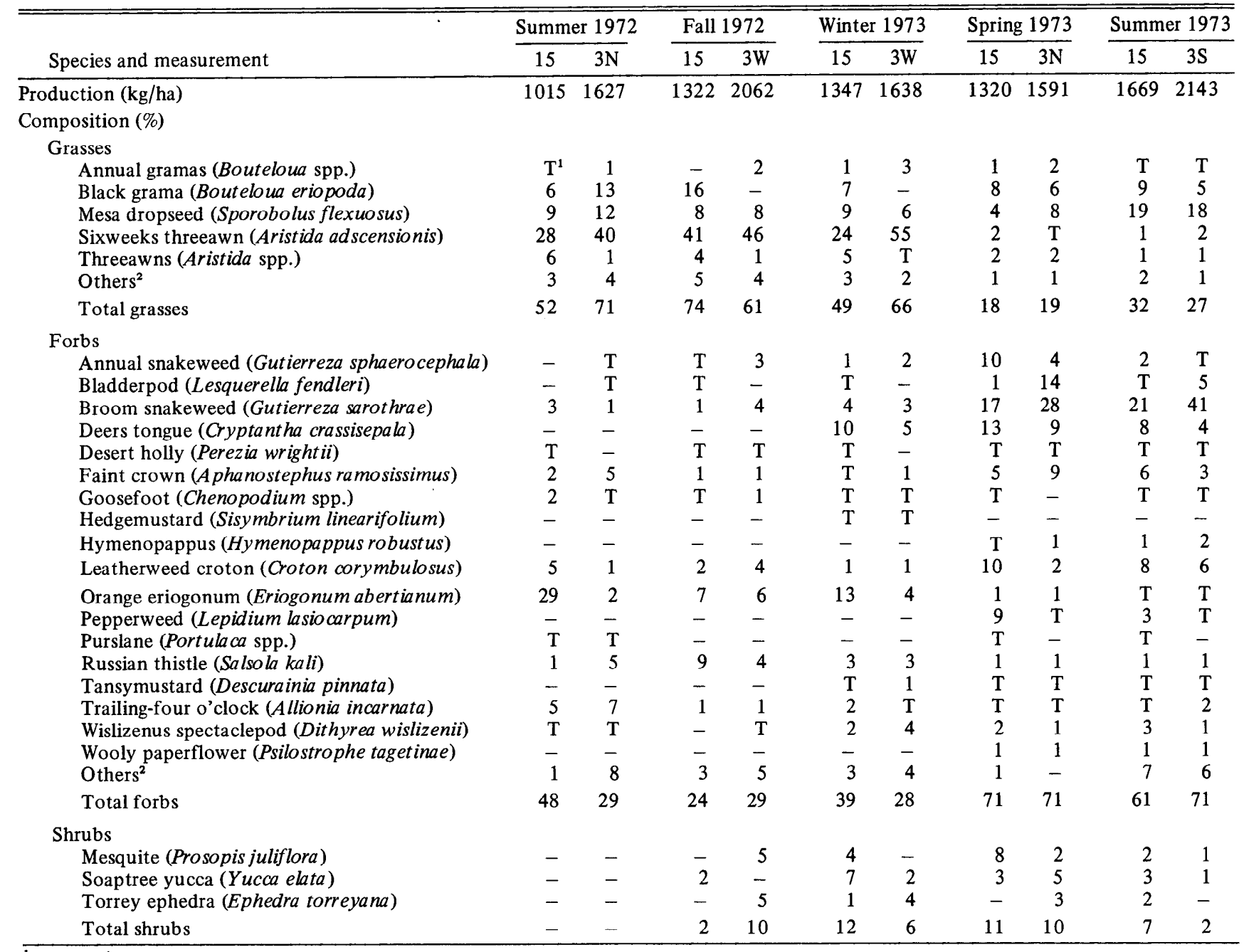

${ }^{1} \mathrm{~T}=0.4 \%$ or less.

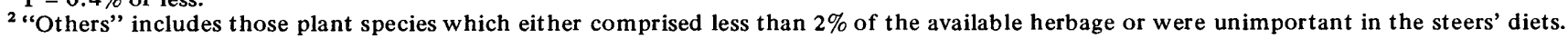

of flower stalks of soaptree yucca in the steers' diets changed from approximately $70 \%$ of spring diets while comprising less than $4 \%$ of available herbage to less than $10 \%$ of summer diets when availability dropped to less than $2 \%$.

The high preference for certain species greatly exceeded those reported for any species growing on shortgrass pastures (Beck, 1969) and sandhill ranges (Scales, 1972). Wallace et al. (1972) noted that on certain sandhill ranges, herbage quantity was sufficient to allow cattle to select their total diets from any one of several species. Similar conditions seldom exist on depleted semidesert ranges having mixed plant communities and this might account for high preference values of certain desert plants. Van Dyne and Heady (1965) concluded that less abundant species usually were either highly selected or rejected, while abundant ones furnished the bulk of diets and appeared to be neither preferred nor avoided.

Observations that cattle graze primarily grass (Cook et al., 1967) were substantiated during certain seasons. Cattle preferences for grasses, however, were often low and quantities of grass consumed depended upon season and on palatability of forbs and shrubs. Grass contents of diets varied from as high as $78 \%$ in summer to as low as $14 \%$ in spring. Herbel and Nelson (1966) reported similar trends.

Mesa dropseed was the most important forage plant, and comprised larger, more consistent portions of diets than any other species. There were not significant season or pasture differences in dietary proportions of dropseed. Cattle grazed less selectively on dead and live dropseed herbage than on any other grass.

Palatability of black grama did not appear as great as reported by early workers (Campbell and Crafts, 1939). Preference for black grama was about average when compared to preferences for other species. Lowest preference occurred in spring while highest preference occurred in winter. Watkins (1955) noted that winter growth activity of black grama increased palatability. This observation was confirmed by highest preference for black grama in the year-long use pasture during winter. Black grama was scarce in pasture $3 \mathrm{~W}$, so winter preference could not be evaluated in the seasonal suitability system. Strong preference was also shown for black grama in pasture $3 \mathrm{~S}$ during summer 1973 when quantities of green forage were limited by drought. Similar findings were reported for cattle diets on semidesert ranges in Arizona (Galt et al., 1969).

Highest grass preferences were obtained for perennial three-awns. Preferences for these grasses were 
Table 3. Botanical composition (\%) and preference rank ${ }^{1}$ of plant species in steer diets on year long (15) and seasonal suitability (3N, $3 \mathrm{~S}$, 3W) pastures.

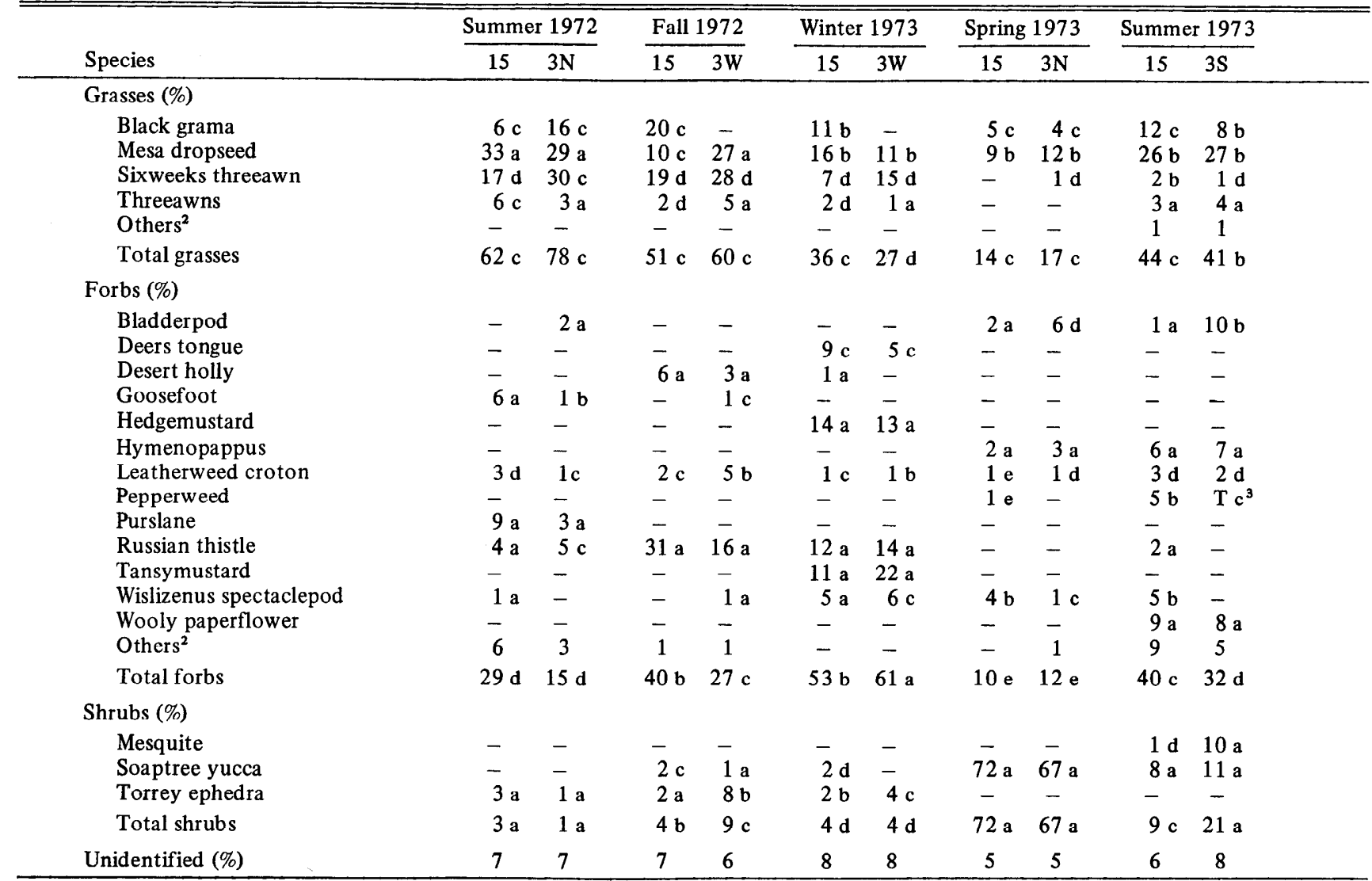

${ }_{1}^{1}$ Preference rank and meanings are derived from the following preference indices:

$\begin{array}{lcl}\text { Preference Index } & \text { Preference Rank } & \text { Meaning } \\ 2.1 \text { or greater } & \text { a } & \text { definite preference } \\ 1.4-2.0 & \text { b } & \text { some preference } \\ 0.7-1.3 & \text { c } & \text { same in diet as available } \\ 0.3-0.6 & \text { d } & \text { some avoidance } \\ 0.2 \text { or less } & \text { e } & \text { avoidance. }\end{array}$

"Others" include plant species which never comprised more than $4 \%$ of the diets for any pasture or 10-day period in the study.

${ }^{3} \mathrm{~T}=\mathbf{0 . 0 4 \%}$ or less.

highest in summer 1973 when preferences for mesa dropseed were lowest. Annual grasses, primarily sixweeks threeawn, contributed substantially to cattle diets especially in late summer and fall after perennial grasses had matured and before decomposition of smaller plants became pronounced.

Forb content in diets varied from $61 \%$ in winter to $10 \%$ in spring and averaged nearly $31 \%$ for all scasons. However, most species of forbs were only eaten at certain seasons. Russian thistle was the most dominant forb in diets, particularly in fall when it composed $31 \%$ of diets under year-long use conditions. Though not always identified histologically, Russian thistle was observed being grazed in every pasture and at every season. Leatherweed croton and Wislizenus spectaclepod consistently made up small portions of diets.
Tansymustard and a hedgemustard were unusually abundant during winter and were the most preferred species during that season. Cattle on other parts of the ranch were observed grazing these forbs persistently. Several cows developed symptoms of tansymustard toxicity, and death of a heifer was attributed to it.

The most dramatic example of selective grazing was soaptree yucca utilization. Steers became adept at locating and cropping developing flower stalks. They spent most of their grazing time searching for yucca plants and would often run to them from

Table 4. Seasonal proportions (\%) of grasses, forb, and shrubs in standing crop and steer diets.

\begin{tabular}{|c|c|c|c|c|c|c|c|}
\hline \multirow[b]{2}{*}{$\begin{array}{l}\text { Year and } \\
\text { season }\end{array}$} & \multicolumn{2}{|c|}{ Grass } & \multicolumn{2}{|c|}{ Forb } & \multicolumn{2}{|c|}{ Shrub } & \multirow{2}{*}{$\begin{array}{l}\text { Unident } \\
\begin{array}{l}\text { Steer } \\
\text { diets }^{1}\end{array}\end{array}$} \\
\hline & $\begin{array}{l}\text { Standing } \\
\text { crop }\end{array}$ & $\begin{array}{l}\text { Steer } \\
\text { diets }^{1}\end{array}$ & $\begin{array}{c}\text { Standing } \\
\text { crop }^{1}\end{array}$ & $\begin{array}{l}\text { Steer } \\
\text { diets }^{1}\end{array}$ & $\begin{array}{l}\text { Standing } \\
\text { crop }^{1}\end{array}$ & $\begin{array}{l}\text { Steer } \\
\text { diets }^{1}\end{array}$ & \\
\hline \multicolumn{8}{|l|}{1972} \\
\hline Summer & $61^{a}$ & $70^{\mathrm{a}}$ & $39 a b$ & $21^{b}$ & $\mathrm{~T}^{*}$ & $2^{b}$ & 7 \\
\hline Fall & $68^{a}$ & $55^{\mathrm{a}}$ & $27 \mathrm{c}$ & $33^{\mathrm{ab}}$ & $6^{a}$ & $6^{b}$ & 6 \\
\hline \multicolumn{8}{|l|}{1973} \\
\hline Winter & $58^{\mathrm{a}}$ & $32^{b}$ & $33^{b c}$ & $57^{\mathrm{a}}$ & $9^{a}$ & $4^{b}$ & 8 \\
\hline Spring & $18^{b}$ & $15^{b}$ & $71^{a}$ & $11^{b}$ & $11^{\mathrm{a}}$ & $69^{a}$ & 5 \\
\hline Summer & $30^{\mathrm{ab}}$ & $42^{\mathrm{ab}}$ & $66^{a b}$ & $36^{a}$ & $5^{a}$ & $15^{\mathrm{b}}$ & 7 \\
\hline Average & 47 & 43 & 47 & 32 & 6 & 19 & 6 \\
\hline
\end{tabular}

${ }^{1}$ Means in the same column with different superscripts are significantly different $(P<.05)$. ${ }^{*} \mathrm{~T}=0.5 \%$ or less. 


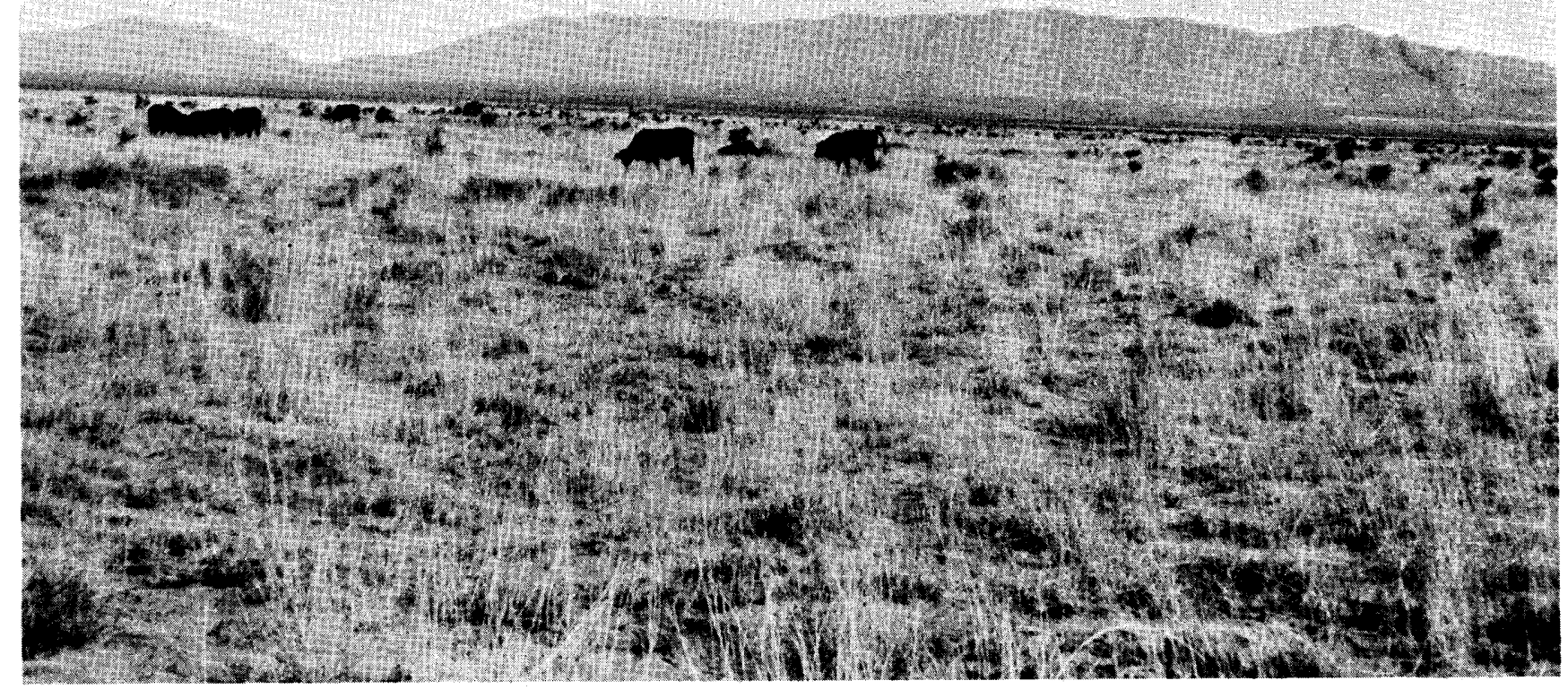

distances of 10 to $15 \mathrm{~m}$. Other cattle in the pastures exhibited similar behavior and rancher observations support these findings.

Mesquite was utilized only in summer 1973 when numerous seedpods were produced. Seedpods constituted most of the consumed material, but small quantities of leaves were also eaten. Higher consumption and preference for mesquite in pasture $3 S$ were attributed to availability of seedpods. Cows had grazed pasture 3S only 2 weeks prior to the collection period and this may have been the reason for more beans being available.

\section{Conclusions}

1) Perennial grasses, while representing dependable sources of forage, never comprised more than $50 \%$ of the steer diets in any season and should not be used as the sole criterion for estimating forage production or quality.

2) Shrubs and ephemeral grasses and forbs comprised over one-half of the steers' diets in certain seasons, and must be utilized when available if any benefit is to be derived from them.
3) Cattle grazing desert grassland utilize a wide variety of plants when available.

\section{Literature Cited}

Beck, R. F. 1969. Diets of steers in southeastern Colorado. PhD Diss. Colorado State Univ., Fort Collins. 55 p.

Campbell, R. S., and E. C. Crafts. 1939. How to keep and increase black grama on southwestern ranges. U.S. Dep. Agr. Leaflet $180.8 \mathrm{p}$.

Cook, C. W., L. E. Harris, and M. C. Young. 1967. Botanical and nutritive content of diets of cattle and sheep under single and common use on mountain range. J. Anim. Sci. 26:1169-1174.

Free, J. C., P. L. Sims, and R. M. Hansen. 1971. Methods of estimating dry-weight composition in diets of steers. J. Anim. Sci. 32:1003-1007.

Galt, H. D., B. Theurer, J. H. Elurenreich, W. H. Hale, and S. C. Martin. 1969. Botanical composition of diet of steers grazing a desert grassland range. J. Range Manage. 22:14-19.

Herbel, C. H., and A. B. Nelson. 1966. Species preferences of Hereford and Santa Gertrudis cattle on a southern New Mexico range. J. Range Manage. 19:177-181.

Leigh, J. H., and W. E. Mulham. 1966. Selection of diet by sheep grazing semi-arid pastures on the Riverine Plain. I. A bladder saltbush (Atriplex vesicania), cotton bush (Kochia aphylla) community. Australian J. Exp. Agr. and Anim. Husb. 6:460-467.

Rosiere, R. E. 1973. Cattle diets on semidesert grassland. MS Thesis. New Mexico State Univ., Las Cruces. 139 p.

Scales, G. H. 1972. Nutritive value and consumption of sandhill range forage by grazing cattle. PhD Diss. Colorado State Univ., Fort Collins. 259 p.

Sparks, D. R., and J. C. Malecheck. 1968. Estimating percentage dry-weight in diets using a microscopic technique. J. Range Manage. $21: 264-265$.

Steel, R. G. D., and J. H. Torrie. 1960. Principles and procedures of statistics. McGraw-Hill Book Co., Inc., New York. $481 \mathrm{p}$.

Thetford, F. O., R. D. Pieper, and A. B. Nelson. 1971. Botanical and chemical composition of cattle and sheep diets on piny on-juniper grassland range. J. Range Manage. 24:425-431.

U. S. Department of Commerce. 1972. Annual summer climatological data, New Mexico. National Oceanic \& Atmospheric Administration. Environmental Data Service. Vol. 76(13):215-228.

Valentine, K. A. 1967. Seasonal suitability, a grazing system for ranges of diverse vegetation types and condition classes. J. Range Manage. 20:395-397.

Wallace, J. D., J. C. Free, and A. H. Denham. 1972. Seasonal changes in herbage and cattle diets on sandhill grassland. J. Range Manage. 25:100-104.

Watkins, W. E. 1955. Digestibility of range grasses and grass-legume mixtures. New Mexico Agr. Exp. Sta. Bull. 400. 22 p. 